\title{
Study on the Factors that Restrict the Development of Intermediate Business of Commercial Banks in China
}

\author{
Dong TAN \\ Department of Finance, Xiamen University, Xiamen, Fujian, China
}

\begin{abstract}
China's marketization of interest rate to promote has increased the risk of bank. Traditional business is restricted. Under this background, the banking intermediary business needs continuous innovation, increase the income of bank. But in general, the starting point of the intermediate business of commercial banks in China is low. The development scope of intermediate business is very small. This paper states the current situation of the development of intermediate business of commercial banks in China, analyzes the factors which restrict the development of intermediate business of commercial banks in China, and gives some suggestions to the development of intermediate business of commercial banks in China.
\end{abstract}

KEYWORD: Intermediary Business; Marketization of Interest Rate; Restricting factors

\section{INTRODUCTION}

Since July 20, 2013, the people's Bank of Chinese fully liberalized financial institutions loan interest rate control. The process of China's interest rate marketization obtained substantial development. This also provides an important foundation for the deposit interest rate of market comprehensive opening. Interest rate marketization is both opportunity and challenge for the development of commercial Banks. China's marketization of interest rate to promote has increased the risk of bank. Traditional business is restricted. Under this background, the banking intermediary business needs continuous innovation, increase the income of bank.

Intermediary business, asset business and liability business are called the three major business of modern commercial Banks. Intermediary business increases the profit source, disperse the risk for commercial banks. The rapid development of intermediate business can greatly improve the capacity of commercial Banks. But in general, the starting point of the intermediate business of commercial banks in China is low. The development scope of intermediate business is very small. The intermediate business of commercial Banks in China is influenced by traditional concepts and system, its development is still in the early stages of slow and cautious.

\section{CURRENT SITUATION OF INTERMEDIATE BUSINESS IN CHINA}

The development of intermediate business of Commercial Bank of our country is very late. Most of intermediate business varieties are labor-intensive products, mainly are clearing, agent. Intermediate business of personal financial management, assets evaluation, credit investigation, futures, options and derivatives and other high technology content in our country are still in the starting stage. Overall, China's commercial banks intermediate business products showed the following characteristics:

First, in a very long time, influenced by strictly separate management and traditional management ideas, most of the intermediary business of our commercial bank are general settlement, remittance, payment and other traditional business generation. Consulting, commissives, wealth management and other higher value-added varieties of intermediary business is a tiny proportion. Financial derivative instrument is in the initial stage.

Second, large state-owned commercial banks and joint-stock commercial banks concentrated almost all kinds of products. A large number of small and medium-sized commercial banks intermediate business only a few varieties. Most banks do not have the distinctive features of the intermediate business. And they have not established the brand effect. The intermediate business of commercial banks have serious homogeneity. 
Third, part of the intermediate business developed very quickly, Such as the debit card business, quasi credit card business, collection and payment services, agency securities, collection and payment services, personal foreign exchange trading, the bank acceptance bill business. However, the other part of intermediate business of higher technology, development speed is slow. Such as cash management, financial consulting, enterprise management consulting business are still in the initial stage.

\section{THE FACTORS THAT RESTRICT THE DEVELOPMENT OF INTERMEDIATE BUSINESS OF COMMERICIAL BANKS IN CHINA}

\subsection{The institutional factors}

In the aspect of legal system, China lacks the relevant laws and regulations to guide and standardize the intermediary business in a long term. There is no clear provisions on the intermediate business charge standard and business scope. In July 2001, the people's bank of China issued "the interim provisions on the intermediate business of commercial bank". In October 2003, the people's bank of China announced "the commercial bank service price management interim measures" .They in a certain extent has solved the problem that commercial bank cost and benefit are inconsistent for a long time. Therefore, the intermediate business of commercial banks in china is restricted by the lag and vacancy of laws and regulations.

In the aspect of financial supervision system, the development of the intermediate business is restricted by the current operation of the financial regulatory system to a certain extent. Thus, the commercial banks cannot design and develop interdisciplinary, comprehensive intermediary business products. However, these businesses tend to bring higher profits for the commercial banks. This makes it difficult to improve commercial bank intermediary business level.

In the aspect of incentive system, at present, the performance appraisal of commercial bank is mainly to loan size, supplemented by asset quality. The intermediate business assessment is not standard, and not influence enough. This led directly to that the grass-roots management layer general lack of understand of the importance of intermediate business.

\subsection{The demand factors}

First, the overall level of economic development in our country is still relatively low, and the marketization degree is not high. Compared with the traditional business, intermediary business is a higher level of service, require consumers have a certain economic strength. The level of development of intermediate business in various countries, is basically related to the level of economic development .But in our country, there are a large part of consumers just need clearing, transfers and other simple intermediate business. To those more complex intermediate business, such as consulting, managing money for clients, there are not much demand.

Second, the concept and the enterprise management level is very backward. At present, most demand of enterprises of our country for banking services are still remain in the loan and other traditional business, and settlement, transfers and other intermediary business. There is not much demand for innovation of financial products.

Third, there is a deviation awareness of the intermediate business in a lot of consumers. Due to the long-term planned economy system, many people subconsciously think that bank is a government department, and rather than a selfsustaining economy. Some intermediary business in the past is a free service for a long time, which makes the consumers who were accustomed to the "free cake" psychologically difficult to accept.

Finally, due to the complexity technology of intermediary business product, this might exclude some low cultural level consumers. Some more complex comprehensive intermediary business, to understanding needs certain professional knowledge. No doubt this intermediate service products formed the obstacle to this part of the consumer.

\subsection{The talent factor}

The lack of talent, hinders the development of intermediary business and innovation. Intermediary business is a knowledge intensive business. It has the features of collection of talent, technology, organization, network, information, funds and credibility. Intermediary business is also a high technology industries in the field of finance. Intermediary business development needs a large number of talents who have broad scope, rich practical experience, and understand technology, good management. The lack of talent make our country commercial bank cannot carry out varieties of high technical content of the business, that restrict the development of intermediary business.

\subsection{The technology factor}

Intermediary business, as one of the modern financial services business, is a collection of science and technology, electronic intelligence and service quality. Although in recent years, the development of commercial bank in the electronic construction is rapid, but this is far behind the needs of the 
development of computer networking, software and application and service function. Intermediary business, especially senior business, need a series of technical support. The higher the value, the higher requirement for technology. The science and technology level of intermediate business in China is low.

\section{PROBLEM OF INTERMEDIATE BUSINESS}

\subsection{Intermediate business innovation ability is low}

American commercial banks are global leader in the development of high technology content and high value-added new products. The commercial bank financial products emerge in an endless stream. According to statistics, the foreign bank's intermediate business products reach more than 20,000 kinds. And innovative products and the intermediate business income generally comes from the high technology.

Compared with other countries, the intermediary business of our commercial bank has obvious disadvantage. Our commercial bank intermediary business products are mainly by copying the mode of developed countries, the lack of features, without originality, level always not to upgrade.

\subsection{The contribution rate of intermediate business to business income is low}

In recent years, the scale of intermediate business of commercial banks in China have been expanding, but due to historical reasons, the development of intermediate business time is too short. So, the intermediate business in commercial banks accounted for the proportion of business income is small. It cannot follow the development of the traditional deposit and loan business. Commercial banks intermediate business income accounted for in the proportion of revenues is low, intermediate business contribution rate is not high.

\subsection{The market competition of intermediate business is disorderly}

The current legislation is not perfect, which makes the competition between commercial banks still cannot reach a standard level. In order to snatch the big industry, big customer deposits, invested a lot of manpower, material resources, financial resources, taking each other to keep the prices down, provide preferential conditions and various unfair competition means to attract customers, in the bank to form a kind of vicious competition situation.

\section{MEASURES FOR THE DEVELOPMENT OF INTERMEDIATE BUSINESS}

There are many different kinds of intermediary business. It has a large potential market. Intermediary business will become the focus of commercial Banks in future. Intermediate business as a new financial products, is always in constant development and innovation. Commercial Banks should choose the right breakthrough point, get the focus and innovation of financial tools and services, to promote the rapid development of intermediary business.

\subsection{Accelerate the cultivation of the talent intermediary business, expand professional talent team.}

First, based on reality, take various forms and channels to conduct professional training for employees, improve the quality of employees, in order to adapt to the need of business.

Second, facing the university, and bring in some college graduates with high theoretical knowledge, enrich the intermediary business development team, and to promote the management and development of the intermediary business.

\subsection{To speed up the pace of construction of science and technology}

Commercial banks should continue to increase investment in science and technology. They also should design and development the intermediate business with high technology, bridge electronic business between banks and customers.

\subsection{Improve the reward incentive mechanism}

Commercial banks should regard the development of intermediate business incorporated into the target responsibility system at all levels of management. They also should be the important basis for the objectives and tasks to complete as leader in performance appraisal.

\section{REFERENCES}

[1] Silber, W.L. "Process of Financial Innovation". American Economic Review, January, 1983.

[2] Shuguang Fan, "The choice of commercial bank intermediary business development", Journal of Financial Research, April, 2004.

[3] Yifei Yin, "The mechanism reform of state-owned commercial Banks: the intermediary business for example", Journal of Financial Research, December, 2011.

[4] Xiaokuan Chen, "The innovation of intermediary business of commercial bank", Journal of Financial Research, March, 2011. 
[5] Yuanhu $\mathrm{Wu}$, "Under the trend of marketization of interest rate of commercial bank sustainable development path selection - based on the thinking of intermediate business", Journal of Financial Research, September, 2012.
[6] Fan Jiang, "How to expand the intermediate business in the process of interest liberalization", Journal of Finance and Economics, February, 2013.

[7] Yuqiao Rui, "Comparative analysis of intermediate business of the Listed Banks", Commercial Research, February, 2012. 